\title{
USE OF HUMIC ACID AND SOME BIOFERTILIZERS TO REDUCE NITROGEN RATES ON CUCUMBER (Cucumis sativus L.) IN RELATION TO VEGETATIVE GROWTH, YIELD AND CHEMICAL COMPOSITION. \\ El-Shabrawy, R. A.*; A.Y. Ramadan* and Sh. M. El-Kady** \\ *Vegt. Ras. Dept., Hort. Res. Inst., Agric. Res. Center, Giza. \\ ${ }^{* *}$ Microbiology Dept., Fac. of Agric., Damiatta, Mansoura University.
}

\begin{abstract}
Two field experiments were carried out during the two summer seasons of 2007 and 2008 at Kaha Hort. Res. Station, Kaliobia Governorete. Humic acid and Azotobacter and Azospirillum as bacteria fixing nitrogen along with nitrogen levels 30 , 60 and $90 \mathrm{~kg} \mathrm{~N} / \mathrm{fed}$. plus uninoculated plants were evaluated under recommended $\mathrm{N}$ dose $120 \mathrm{~kg} \mathrm{~N} / \mathrm{fed}$., in addition to their interaction on growth, yield and chemical composition of cucumber plants. A split plot design with three replicates was used. The results revealed that, humic acid at $0.5 \%$ as soil application increased the vegetative growth expressed as number of leaves, plant height $(\mathrm{cm})$, plant fresh and dry weight $(\mathrm{gm})$ and leaf area $\left(\mathrm{cm}^{2}\right)$ and increased significantly fruits/plant, plant yield (kg/fed.) Early and total yield (ton/fed.).

Also, soil application of humic acid at $0.5 \%$ had significant effect on nitrogen, phosphours and potassium. However, $\mathrm{NO}_{3}$ in cucumber fruits was not significantly affected with humic acid.

Biofertilizers (Azotobacter and Azospirillum as bacteria fixing nitrogen had a significant on all studied character in both seasons, the highest values were obtained by inoculation cucumber plants with Azotobacter and $90 \mathrm{~kg} \mathrm{~N} / \mathrm{fed}$.

The interaction between humic acid and biofertilizers plus nitrogen levels had significant effect on all treats under study in both seasons.

Generally, it could be concluded that, soil application of humic acid at $0.5 \%$ twice after 36 and 50 day after sowing at rate $25 \mathrm{ml} / \mathrm{plant}$ and inoculation plants with Azotobacter after 30 day after sowing at rate $25 \mathrm{ml} /$ plant along with $90 \mathrm{~kg} \mathrm{~N} / \mathrm{fed}$ gave the highest values of yield and NO3- concentration on cucumber fruits were within the safe levels from human
\end{abstract}

\section{INTRODUCTION}

Cucumber (Cucumis sativus L.) is one of the important cucurbiteous crops grown in Egypt. The cultivated open field area reached 71932 feddan with average yield of 9.33 ton /fed. The excess use of nitrogen fertilizers in agriculture can lead to nitrate accumulation in plants and ground water pollution, nitrate accumulation in edible plants is a problem when eaten, part of ingested nitrate may be converted to nitrite causing methaemoglobinaemia or oveeen to carcinogenic nitrosamines (Alexander, 1977).

Accordingly, active researches must be conducted to find ways of reducing nitrate accumulation in vegetable crops.

Humic acid had significant effect on vegetative growth and yield of potato plants (Awad and El-Ghamry 2007). Enhancement of plant growth using humic acid had been reported to be due to increasing nutrients uptake 
such as N, Ca, P, K, Mg, Fe, Zn and Cu (Adani, et al 1998 and David, et al 1994), and enhancement of photosynthesis, chlorophyll density and plant root respiration has resulted in greater plant growth with humate application (Chen and Avaid 1990 and Smidova 1960). The application of biofertilizers to avoid environmental pollution. Azotobacter and Azospirillum were found to have not only the ability to fix nitrogen but also to release certain phytohormones of gibberelline and indolic nature, which could stimulate plant growth, absorption of nutrients and photosynthesis process (Tien et al., 1979; Rynders and Vlassak, 1982 and Fayez et al., 1985).

Azotobacter is also known to produce an either soluble fungistatic substance which inhibits the growth of fungi like Alternaria, Fusarium and Rhizoctonia solani (Gupta et al., 1995). Single inoculation of cucumber and tomato plants with Azotobacter caused an increase in nitrogen content by 44.3 and $50 \%$ in cucumber and tomato plants compared with uninoculated plants, respectively (Gomaa, 1995). Gharib (2001) found that inoculated cucumber plants with Azotobacter plus phosphate dissolving bacteria (PDB) led to significant increases in early and total yield at the half dose of the normal mineral nitrogen. Also, Hanna et al., 2005 found that application of chicken manure with biofertilizers (Azotobacter + Azospirillum) significantly increased vegetative growth and early and total yield of cucumber.

The objective of the present work was to study the effect of humic acid and inoculation with Azotobacter and Azospirillum plus different doses of Nchemical fertilizer $(30,60$ and $90 \mathrm{~kg} \mathrm{~N} / \mathrm{fed}$. Unicoulated plants received the recommended $\mathrm{N}$-dose $(120 \mathrm{~kg} \mathrm{~N} / \mathrm{fed})$ were also involved on vegetative growth, yield and its components and chemical composition on cucumber plants.

\section{MATERIALS AND METHODS}

Two field experiments were carried out during the two summer seasons of 2007 and 2008 at Kaha Hort. Res. Station, Kaliobia Governorete to study the effect of humic acid and Azotobacter and Azospirillum as bacteria fixing nitrogen and nitrogen N-levels 30,60 and $90 \mathrm{~kg} \mathrm{~N} / \mathrm{fed}$. plus unicoulated plants received the recommended $\mathrm{N}$ dose $120 \mathrm{~kg} \mathrm{~N} / \mathrm{fed}$., on growth, yield and chemical composition of cucumber plants.

Physical properties for experimental soil (texture class) was clayey and $\mathrm{pH} 7.9$ and 8.1 in the first and second year, respectively. The experimental was carried out in a split plots design with three replications. The main plots were included humic acid and without humic which subdivided to seven sub plots (recommended dose $120 \mathrm{~kg} \mathrm{~N} / \mathrm{fed}, 3 / 4 \mathrm{R}$-dose + Azotobacter, 3/4 R-dose + Azospirillum, $1 / 2 \mathrm{R}$-dose + Azotobacter, $1 / 2 \mathrm{R}$-dose + Azospirillum, $1 / 4 \mathrm{R}$-dose + Azotobacter, $1 / 4 \mathrm{R}$-dose + Azospirillum) the experiment includes 14 treatments, which were the combination between two humic acid and 7 biofertilizer and nitrogen levels.

Cucumber seeds (Amira II hybrid were sown on the second week of March for both seasons of study. Seeds were sown in hills $30 \mathrm{~cm}$ apart on one side of ridge of 5 meters in length and one meter in width. Thinning took 
place after complete germination, i.e., two weeks after seed sowing, leaving one plant per hill. The sub plot area was $15 \mathrm{~m}^{2}$ and each one consisted of three rows. Three commercial fertilizers were used; ammonium nitrate $(33 \%$ $\mathrm{N})$, calcium super phosphate $\left(15.5 \% \mathrm{P}_{2} \mathrm{O}_{5}\right)$ and potassium sulphate $(48 \%$ $\mathrm{K}_{2} \mathrm{O}$ ). In applying the fertilizers, the quantity devoted for each plot was divided as follows:

-Nitrogen fertilizer treatments was divided into three equal parts; the first was added after three weeks from sowing, the second after two weeks from first part and third two weeks after second part latter.

- Phosphorus fertilizer was divided into two equal parts; the first was applied to soil before sowing and second after three weeks from sowing.

- Potassium fertilizer was divided into equal parts, the first was added after three weeks from sowing and the second after two weeks ( 36 days after sowing).

Humic acid at $0.5 \%$ was added beside cucumber plants after 36 and 50 days after sowing. An efficient of Azotobacter chroococcum and Azospirillum lipoferum were obtained from microbial collection of Dept. Agric. Microbiology, Fac. Agric. Ein Shams University, Cairo, Egypt.

The mother culture of Azotobacter strain was grown on modified a Shhy's medium of Abdel-Malek and Ishac (1968) while Azospirillum isolate was grown on nutrient broth medium oxoid Manual, (1965). Inoculum was prepared by subculturing the Azotobacter and Azospirillum mother culture on nutrient agar in kolle flasks for $72 \mathrm{hr}$, after which the heavy growth was then scratched and transferred sterile tap water and thoroughly mixed. The prepared inoculum was then used to inoculate plants at rate of $25 \mathrm{ml} / \mathrm{plant}$ after one month from planting bacterial growth conditions: total bacteria counts was determined on nutrient agar medium (Difeo Manual, 1977 at $30^{\circ} \mathrm{C}$ for 48 to $72 \mathrm{hr}$. But Azotobacter and Azospirillum were calculated on Ashby's medium Abdel-Malek and Ishad, (1968) and Dobereiner, (1988) media at $30^{\circ} \mathrm{C}$ for 10 days, respectively.

A random sample of five plants from each sub plot were taken at the flowering stage for determination of vegetative growth, i.e., plant height, number of leaves, plant fresh and dry weight and leaf area $(\mathrm{cm} 2)$ of the six leaf from the meristemic top of the main stem.

Number of fruits/plant, plant yield $(\mathrm{kg}$ ), early yield (ton/fed) fruits of first six harvests from each treatment were weighted to calculate the early yield per fed. and total yield (ton/fed.). All fruits harvested from each treatment through harvesting period were weighted to calculate the total yield per fed.

Total nitrogen, phosphorus and potassium were determined in leaves at the beginning of flowering according to the method described by Pregl (1945), Murphy and Riley (1962) and Brown and Lilleland (1946). Nitrate was determined in fruits according to Singh (1988).

All obtained data were statistically analyzed for variance and the mean values were compared at $5 \%$ levels of LSD according to (Snedecor and Cochran, 1980). 


\section{RESULTS AND DISCUSSION}

\section{Vegetative growth parameters: \\ Effect of humic acid}

Data recorded in table (1) explain that growth parameters of cucumber plants expressed as No. of leaves, plant height $(\mathrm{cm})$, plant fresh and dry weight $(\mathrm{gm})$ and leaf area $\left(\mathrm{cm}^{2}\right)$ were significantly influenced by humic acid however, number of leaves and fresh weight were not significantly affected in the second season. The highest values of most these traits were obtained by soil application of humic acid. These results could be due to the role of humic acid which enhance photosynthetic process, stimulate root growth and development of chlorophyll and proliferation of desirable micro-organisms in soil (Liu et al., 1998).

Table (1): Effect of humic acid and biofertilizers on plant vegetative growth of cucumber during 2007 and 2008 seasons.

\begin{tabular}{|c|c|c|c|c|c|c|c|c|c|c|}
\hline \multirow[t]{2}{*}{ Treatments } & \multicolumn{2}{|c|}{ No. of leaves } & \multicolumn{2}{|c|}{$\begin{array}{l}\text { Plant height } \\
\text { (cm) }\end{array}$} & \multicolumn{2}{|c|}{$\begin{array}{l}\text { Plant fresh } \\
\text { weight (gm) }\end{array}$} & \multicolumn{2}{|c|}{$\begin{array}{c}\text { Plant dry } \\
\text { weight (gm) }\end{array}$} & \multicolumn{2}{|c|}{ Leaf area $\left(\mathrm{cm}^{2}\right)$} \\
\hline & 2007 & 2008 & 2007 & 2008 & 2007 & 2008 & 2007 & 2008 & 2007 & 2008 \\
\hline Humic acid & 24.38 & 22.71 & 104.38 & 107.95 & 339.05 & 340.90 & 44.07 & 44.54 & 182.81 & 159.95 \\
\hline Without & 21.86 & 21.57 & 98.24 & 89.20 & 331.33 & 329.86 & 42.35 & 42.56 & 165.86 & 147.76 \\
\hline L.S.D at $5 \%$ & 0.82 & n.s & 4.1 & 18.12 & 7.08 & n.s & 1.7 & 0.78 & 7.7 & 9.42 \\
\hline \begin{tabular}{|ll}
120 & $\mathrm{~kg}$ \\
$\mathrm{~N} / \mathrm{fed}(\mathrm{R})$ &
\end{tabular} & 25.0 & 23.7 & 111.16 & 97.83 & 357.00 & 342.5 & 45.88 & 44.08 & 186.66 & 162.83 \\
\hline Azt. + $3 / 4 \mathrm{R}$ & 29.0 & 26.5 & 115.66 & 101.50 & 364.33 & 365.00 & 48.25 & 48.02 & 197.83 & 169.66 \\
\hline Azs. + $3 / 4 R$ & 21.5 & 21.3 & 105. & 106.33 & 354.50 & 343.3 & 44.81 & 44.03 & 179.33 & 156.83 \\
\hline Azt. + 1/2 R & 24.16 & 23.0 & 104.66 & 105.16 & 334.0 & 336.33 & 42.30 & 44.25 & 175.5 & 155.66 \\
\hline Azs. $+1 / 2 R$ & 20.8 & 20.17 & 98.0 & 98.16 & 326.33 & 332.33 & 41.12 & 43.11 & 169.3 & 151.16 \\
\hline Azt. $+1 / 4 \mathrm{R}$ & 22.16 & 21.0 & 89.3 & 94.00 & 313.33 & 317.5 & 41.04 & 41.78 & 159.2 & 142.83 \\
\hline Azs. + 1/4R & 19.2 & 19.33 & 84.5 & 87.00 & 305.50 & 310.67 & 39.08 & 39.62 & 152.00 & 138.00 \\
\hline L.S.D at $5 \%$ & $0 . .32$ & 1.19 & 2.9 & n.s & 3.95 & 11.83 & 1.68 & 0.81 & 4.93 & 3.1 \\
\hline
\end{tabular}

In addition, Atiyeh et al., (2002) found that increasing humic acid from 50 to $500 \mathrm{mg} / \mathrm{kg}$ soil significantly increased growth of cucumber plants in terms of plant height, leaf area, shoot, root and dry weight. The beneficial effects of humic acid have been attributed to improvements in soil properties and structure (Kahsnitz 1992), to greater availability of mineral nutrients to plants (Gilot 1997) and increased microbial population and biologically active metabolites such as plant growth regulators (Tomati and Gali, 1995).

\section{Effect of biofertilizers}

Data in table (1) show that growth parameters of cucumber plants i.e., number of leaves and leaf area were reduced by nitrogen stress $(30 \mathrm{~kg} / \mathrm{fed})$ in both season. Similar results were obtained by Byari and Mirdad (1996), they found that reducing nitrogen stress by increasing the level of nitrogen application of 10 to $300 \mathrm{~kg} \mathrm{~N} / \mathrm{ha}$ increased plant growth.

\section{Effect of interaction between humic acid and biofertilizers}

The interaction between humic acid and Azotobacter and Azospirillum had a significant effects on plant height, plant fresh and dry weight and leaf area in both seasons (Table 2). 
Table (2): Vegetative growth of cucumber plant as affected by interaction between humic acid and biofertilizers during 2007 and 2008 seasons.

\begin{tabular}{|c|c|c|c|c|c|c|c|c|c|c|}
\hline \multirow[t]{2}{*}{ Treatments } & \multicolumn{2}{|c|}{$\begin{array}{l}\text { No. of } \\
\text { leaves }\end{array}$} & \multicolumn{2}{|c|}{$\begin{array}{l}\text { Plant height } \\
\text { (cm) }\end{array}$} & \multicolumn{2}{|c|}{$\begin{array}{l}\text { Plant fresh } \\
\text { weight (gm) }\end{array}$} & \multicolumn{2}{|c|}{$\begin{array}{c}\text { Plant dry } \\
\text { weight (gm) }\end{array}$} & \multicolumn{2}{|c|}{$\begin{array}{l}\text { Leaf area } \\
\text { (cm2) }\end{array}$} \\
\hline & 2007 & 2008 & 2007 & 2008 & 2007 & 2008 & 2007 & 2008 & 2007 & 2008 \\
\hline $120 \mathrm{kgN} / \mathrm{fed}(\mathrm{R}$ & 26.30 & 25.33 & 114.66 & 117.33 & 361.66 & 346.67 & 48.13 & 45.83 & 195.00 & 166.00 \\
\hline I $A$ Azt. + 3/4R & 0.32 & 28.00 & 19.66 & 122.33 & & & & 9.33 & & \\
\hline 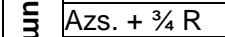 & 2.33 & 21.33 & & 106.33 & 33 & & 46.76 & 5.10 & 56 & \\
\hline 亏Azt. + $1 / 2 R$ & 5.67 & 22.70 & 7.33 & 115.33 & 337.33 & 339.33 & 41.76 & 44.63 & 180.00 & \\
\hline$\cong$ Azs. +1/2R & 1.67 & 20.30 & .33 & 106.30 & 33 & 39.70 & 40.56 & 4.55 & & \\
\hline Azt. +1/4R & 23.66 & 21.33 & 92.66 & 97.33 & 315.00 & 320.00 & 41.26 & 42.10 & 175.00 & 155.67 \\
\hline Azs. $+1 / 4 R$ & 20.68 & 20.00 & 87.33 & 90.67 & 309 & 314.00 & 39.66 & 40.24 & 165.00 & 0.33 \\
\hline $\mathrm{V} / \mathrm{fed}(\mathrm{R}$ & 23.66 & 22.00 & 107.66 & 78.33 & 352.33 & 38.33 & 43.36 & 42.24 & 178.33 & 159.67 \\
\hline$\overline{A z}$ & 27.66 & 25.00 & & & & & 46. & & & \\
\hline$\sum A z$ & 20.60 & 21.30 & & 106.33 & 341.67 & & 42.85 & 2.96 & 175.00 & \\
\hline Fat. +1/2R & 22.66 & 23.30 & 102.00 & 95.00 & 330.66 & 333.30 & 42.83 & 43.86 & 171.00 & 150.67 \\
\hline Azs. +1/2R & 20.00 & 20.00 & 92.66 & 90.00 & 322.33 & 325.00 & 41.67 & 41.66 & 164.33 & 148.0 \\
\hline Azt. + 1/4 R & 20.66 & 20.66 & 87.00 & 90.66 & 312.33 & 315.01 & 40.82 & 41.45 & 143.33 & 130.00 \\
\hline Azs. +1/4R & 17.66 & 18.66 & 81.66 & 83.33 & 301.67 & 307.30 & 38.50 & 38.99 & 139.00 & 125.60 \\
\hline S.D at 5 & 0.45 & 1.78 & 4.08 & 38.13 & 5.58 & \begin{tabular}{|l|}
17.66 \\
\end{tabular} & 2.38 & 1.21 & 6.97 & 4.38 \\
\hline
\end{tabular}

R: Recommended dose (120 kg N/fed.). Azt: Azotobacter Azs: Azospirillum

Data indicate that the highest values were recorded with soil application of humic acid along with $3 / 4$ recommended dose of $\mathrm{N}$-chemical fertilizer $(90 \mathrm{~kg} \mathrm{~N} / \mathrm{fed})$ and inoculated cucumber plants with Azotobacter. The lowest values were obtained without soil application of humic acid along with inoculated cucumber plants with Azospirillum and $30 \mathrm{~kg} \mathrm{~N} / \mathrm{fed}$. Such results could be due to enhancement of plant growth after using humic acid. Increasing nutrients uptake such as $\mathrm{N}, \mathrm{P}, \mathrm{Ca}, \mathrm{K}, \mathrm{Mg}, \mathrm{Fe}, \mathrm{Zn}$ and $\mathrm{Cu}$ is illustrated in this respect (Adani et al., 1998 and David et al., 1994).

Also, such results may suggest that $\mathrm{N}$-fixing bacteria (Azotobacter and Azospirillum) have the ability to supply the grown plants with some their nitrogen requirements, in addition to their ability to release plant promoting substances, mainly IAA, gibrillin and cytokinine-like substances which could stimulate plant growth absorption of nutrients and efficiency of nutrient and the metabolism of phyosynthates (Dobereiner, 1988; Tien et al., 1979; Reynders and Vlassak, 1982).

\section{Yield and its components}

\section{Effect of humic acid}

Results in table (3) show that soil application of humic acid significantly increased the number of fruits/plant, yield (kg/plant) and early and total yield of cucumber plants in both seasons. Similar results were obtained by Awad and El-Ghamry (2007). Results illustrated by Chen and Aviad (1990) demonstrated that humic materials led to increase the permeability of plant membranes, promote the uptake of nutrients, increase soil moisture holding capacity, improve soil, reduce impacts of disease and stimulate plant growth.

\section{Effect of biofertilizers}

Data in table (3) show that inoculated cucumber plants with (Azotobacter and Azospirillum) significantly increased number of fruits/plant, yield of plant $(\mathrm{kg})$ and early and total yield. The highest values were obtained 
by inoculated cucumber plants with Azotobacter along with $3 / 4$ recommended dose of $\mathrm{N}$-chemical fertilizer (90 kg N/fed.) and the lowest values were obtained by inoculated plants with Azospirillum and 1/4 recommended dose of $\mathrm{N}$-chemical fertilizer ( $30 \mathrm{~kg} \mathrm{~N} / \mathrm{fed}$.) These results are in agreement with that reported by Gharib 2001 and Hanna, et al., (2005) on cucumber.

Table (3): Effect of humic acid and biofertilizers on yield and its component of cucumber during 2007 and 2008 seasons.

\begin{tabular}{|c|c|c|c|c|c|c|c|c|}
\hline \multirow[t]{2}{*}{ Treatments } & \multicolumn{2}{|c|}{$\begin{array}{c}\text { No. of } \\
\text { fruits/plant }\end{array}$} & \multicolumn{2}{|c|}{ Plant yield $(\mathbf{k g})$} & \multicolumn{2}{|c|}{$\begin{array}{c}\text { Early yield } \\
\text { (ton/fed) }\end{array}$} & \multicolumn{2}{|c|}{$\begin{array}{c}\text { Total yield } \\
\text { (ton/fed) }\end{array}$} \\
\hline & 2007 & 2008 & 2007 & 2008 & 2007 & 2008 & 2007 & 2008 \\
\hline Humic acid & 10.18 & 10.31 & 1.08 & 1.09 & 4.76 & 4.81 & 13.65 & 13.92 \\
\hline Without & 8.75 & 7.93 & 0.84 & 0.91 & 4.07 & 3.72 & 11.67 & 10.68 \\
\hline L.S.D at $5 \%$ & 0.26 & 0.7 & 0.07 & 0.04 & 0.28 & 0.45 & 0.78 & 1.16 \\
\hline 120 kg N/fed.(R) & 9.35 & 9.98 & 1.05 & 0.97 & 4.18 & 4.47 & 12.51 & 13.41 \\
\hline Azt. $+3 / 4$ R & 10.41 & 10.74 & 1.12 & 1.09 & 4.9 & 5.13 & 13.69 & 14.38 \\
\hline Azs. $+3 / 4 R$ & 10.35 & 10.08 & 1.08 & 1.07 & 4.7 & 4.67 & 13.65 & 13.82 \\
\hline Azt. + $1 / 2 \mathrm{R}$ & 9.65 & 9.26 & 0.97 & 1.04 & 4.61 & 4.47 & 12.92 & 12.45 \\
\hline Azs. $+1 / 2 R$ & 9.35 & 8.4 & 0.88 & 1.02 & 4.57 & 3.74 & 13.23 & 11.28 \\
\hline Azt. + 1/4 R & 8.61 & 7.74 & 0.82 & 0.92 & 4.20 & 3.73 & 11.73 & 10.45 \\
\hline Azs. + 1/4R & 8.25 & 7.65 & 0.81 & 0.87 & 3.75 & 3.55 & 10.86 & 10.30 \\
\hline L.S.D at $5 \%$ & 0.46 & 0.57 & 0.05 & 0.08 & 0.39 & 0.31 & 0.97 & 0.68 \\
\hline
\end{tabular}

\section{Effect of interaction between humic acid and biofertilizers}

The interaction between humic acid and inoculated cucumber plant with Azotobacter and Azospirillum had a significant effects on yield of plant $(\mathrm{kg})$ and early and total yield in both seasons (table 4).

Table (4): Yield and its components as affected by interaction between humic acid and biofertilizers on cucumber during 2007 and 2008 seasons.

\begin{tabular}{|c|c|c|c|c|c|c|c|c|c|}
\hline \multirow{2}{*}{\multicolumn{2}{|c|}{ Treatments }} & \multicolumn{2}{|c|}{$\begin{array}{c}\text { No. of } \\
\text { fruits/plant }\end{array}$} & \multicolumn{2}{|c|}{ Plant yield $(\mathbf{k g})$} & \multicolumn{2}{|c|}{$\begin{array}{c}\text { Early yield } \\
\text { (ton/fed) }\end{array}$} & \multicolumn{2}{|c|}{$\begin{array}{c}\text { Total yield } \\
\text { (ton/fed) }\end{array}$} \\
\hline & & 2007 & 2008 & 2007 & 2008 & 2007 & 2008 & 2007 & 2008 \\
\hline \multirow{7}{*}{ 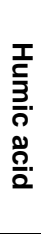 } & $120 \mathrm{~kg} \mathrm{~N} / \mathrm{fed}(\mathrm{R})$ & 9.5 & 11.13 & 1.16 & 0.99 & 4.17 & 4.98 & 12.53 & 14.95 \\
\hline & Azt. + 3/4 R & 11.4 & 12.35 & 1.27 & 1.22 & 5.51 & 5.88 & 15.37 & 16.84 \\
\hline & Azs. + 3/4 R & 11.30 & 11.16 & 1.20 & 1.18 & 5.20 & 5.36 & 15.03 & 15.52 \\
\hline & Azt. + 1/2 R & 11.03 & 10.50 & 1.10 & 1.16 & 5.01 & 5.08 & 14.00 & 14.11 \\
\hline & Azs. + $1 / 2 R$ & 10.10 & 9.60 & 1.00 & 1.15 & 5.08 & 4.13 & 14.76 & 12.87 \\
\hline & Azt. + 1/4 R & 9.13 & 8.80 & 0.93 & 1.00 & 4.46 & 4.24 & 12.48 & 11.89 \\
\hline & Azs. $+1 / 4 R$ & 8.80 & 8.63 & 0.90 & 0.93 & 3.90 & 3.99 & 11.36 & 11.63 \\
\hline \multirow{8}{*}{$\frac{\sum}{\stackrel{\sum}{\text { 을 }}}$} & $120 \mathrm{~kg} \mathrm{~N} / \mathrm{fed}(\mathrm{R})$ & 9.20 & 8.82 & 0.93 & 0.95 & 4.18 & 3.97 & 12.49 & 11.89 \\
\hline & Azt. + 3/4 R & 9.41 & 9.13 & 0.96 & 0.97 & 4.29 & 4.38 & 12.00 & 12.29 \\
\hline & Azs. + 3/4 R & 9.41 & 9.00 & 0.95 & 0.97 & 4.23 & 4.16 & 12.26 & 12.12 \\
\hline & Azt. + $1 / 2 \mathrm{R}$ & 8.86 & 8.03 & 0.84 & 0.92 & 4.22 & 3.85 & 11.83 & 10.82 \\
\hline & Azs. + 1/2 R & 8.60 & 7.20 & 0.75 & 0.90 & 4.04 & 3.34 & 11.70 & 9.70 \\
\hline & Azt. + 1/4 R & 8.10 & 6.68 & 0.70 & 0.85 & 3.94 & 3.22 & 10.96 & 9.01 \\
\hline & Azs. +1/4 R & 7.70 & 6.67 & 0.70 & 0.81 & 3.61 & 3.09 & 10.35 & 8.98 \\
\hline & L.S.D at $5 \%$ & 0.65 & 0.81 & 0.07 & 0.12 & 0.48 & 0.43 & 1.38 & 0.96 \\
\hline
\end{tabular}

R: Recommended dose (120 kg N/fed.). Azt: Azotobacter Azs: Azospirillum 
Data indicate that the highest values were obtained by soil application of humic acid and inoculated cucumber plants with Azotobacter along with $3 / 4$ recommended dose of $\mathrm{N}$-chemical fertilizer ( $90 \mathrm{~kg} \mathrm{~N} / \mathrm{fed}$.) And, the lowest values were obtained without soil application of humic acid and inoculated cucumber plants with Azospirillum which gave the lowest values of plant growth. Similar results were obtained by Byari and Mirdad 1996. Also, Hammad and Abdel-Ati (1998) found that on potato fixed amount of nitrogen by Azospirillum was les than $20 \mathrm{~kg} \mathrm{~N} / \mathrm{fed}$. Subba Rao (1982) reported that Azospirillum on certain varieties of corn may fix a maximum of $20 \mathrm{~kg}$ $\mathrm{N} / \mathrm{fed} /$ year.

Table (5): $\mathrm{N} \%, \mathrm{P} \%, \mathrm{~K} \%$ and $\mathrm{NO}_{3}^{-}$(ppm) of cucumber as affected by humic acid and biofertilizers during 2007 and 2008 seasons.

\begin{tabular}{|c|c|c|c|c|c|c|c|c|}
\hline \multirow{2}{*}{ Treatments } & \multicolumn{2}{|c|}{$\mathbf{N} \%$} & \multicolumn{2}{|c|}{$\mathbf{P} \%$} & \multicolumn{2}{|c|}{ K \% } & \multicolumn{2}{|c|}{$\mathrm{NO}_{3}^{-}$(ppm) } \\
\hline & 2007 & 2008 & 2007 & 2008 & 2007 & 2008 & 2007 & 2008 \\
\hline Humic acid & 2.11 & 1.99 & 0.201 & 0.188 & 2.47 & 2.40 & 65.47 & 66.47 \\
\hline Without & 1.77 & 1.87 & 0.157 & 0.170 & 2.04 & 2.22 & 58.41 & 60.47 \\
\hline L.S.D at $5 \%$ & 0.09 & 0.09 & n.s & 0.011 & 0.28 & 0.16 & n.s & n.s \\
\hline 120 kg N/fed.(R) & 2.99 & 2.98 & 0.233 & 0.223 & 2.49 & 2.76 & 93.3 & 101.0 \\
\hline Azt. $+3 / 4 \mathrm{R}$ & 1.92 & 2.15 & 0.184 & 0.210 & 2.40 & 2.73 & 63.00 & 71.00 \\
\hline Azs. + 3/4 R & 1.86 & 1.95 & 0.183 & 0.190 & 2.37 & 2.47 & 62.37 & 57.00 \\
\hline Azt. + 1/2 R & 1.83 & 1.73 & 0.176 & 0.170 & 2.30 & 2.23 & 60.50 & 56.00 \\
\hline Azs. + $1 / 2 R$ & 1.83 & 1.65 & 0.174 & 0.160 & 2.28 & 2.09 & 53.35 & 55.00 \\
\hline Azt. + $1 / 4 \mathrm{R}$ & 1.63 & 1.53 & 0.155 & 0.150 & 1.99 & 1.93 & 50.95 & 51.50 \\
\hline Azs. + 1/4R & 1.53 & 1.53 & 0.148 & 0.150 & 1.94 & 1.94 & 50.13 & 51.17 \\
\hline L.S.D at $5 \%$ & 0.15 & 0.12 & 0.014 & 0.01 & 0.16 & 0.18 & 12.63 & 10.15 \\
\hline
\end{tabular}

\section{Chemical composition \\ Effect of humic acid}

Data in table (5) show that nitrogen, phosphorus and potassium were significantly influenced by soil application of humic acid in both seasons. These results may suggest that humic acid stimulate root growth and enable better uptake of nutrients (Liu et al., 1998; Zhang et al., 2003; Awad and ElGhamry 2007). Data in table (5) show also that nitrate concentration (ppm) was not significantly affected by soil application of humic acid in both seasons.

\section{Effect of biofertilizers}

Data in table (5) indicate that minerals content and NO3 concentration were significantly affected by biofertilizers. The highest contents were obtained by fertilization cucumber plants with $120 \mathrm{~kg} \mathrm{~N} / \mathrm{fed}$. (unioculated plants). Mahmoud et al., 2009 on cucumber found that mineral nitrogen in cucumber led to a clear increase in nitrogen-\% and nitrate concentration in cucumber leaves and fruits and higher than N\% organic. Similar findings were obtained by Anga (2001) who found an in line in nitrate concentration on spinach leaves with mineral $\mathrm{N}$-fertilizer. On the other hand, the lowest values were obtained by inoculated cucumber plant with Azospirillum along with 30 $\mathrm{kg} \mathrm{N} / \mathrm{fed}$ in both seasons. 
Table (6): $\mathrm{N} \%, \mathrm{P} \%, \mathrm{~K} \%$ and $\mathrm{NO}_{3}^{-}(\mathrm{ppm})$ of cucumber as affected by interaction effect between humic acid and biofertilizers on cucumber during 2007 and 2008 seasons.

\begin{tabular}{|l}
\hline \multirow{2}{*}{ Treatments } \\
\cline { 2 - 10 }
\end{tabular}

\section{Effect of interaction between humic acid and biofertilizers}

The interaction effect between humic acid and inoculated cucumber plants with Azotobacter and Azospirillum had a significant effect on N,P,K and $\mathrm{NO}_{3}$ in both seasons (table 6).

Results indicate that the highest values were obtained by soil application of humic acid and $120 \mathrm{~kg} \mathrm{~N} / \mathrm{fed}$. (recommended dose of $\mathrm{N}$ chemical fertilizer). The lowest values were obtained without soil application of humic acid and inoculated plants with Azospirillum. Such results may indicate enhancement of plant growth using humic acid had been reported to be due to increasing nutrients uptake such as $\mathrm{N}, \mathrm{P}, \mathrm{K}, \mathrm{Ca}, \mathrm{Mg}, \mathrm{Fe}, \mathrm{Zn}$, and $\mathrm{Cu}$ (Adani et al., 1998 and David et al., 1994). And N-chemical fertilizer led to increase $\mathrm{N}$-uptake than $\mathrm{N}$-organic which is low release (Mahmoud et al., 2009), and inoculated with Azospirillum fixed nitrogen less than $20 \mathrm{~kg} \mathrm{~N} / \mathrm{fed}$ (Hammad and Abdel-Ati 1998 and Abdel-Ati et al., 1996).

Humic acid addition increase the total bacterial count in all treatments but it had a negative effect on both Azotobacter and Azospirillum counts (Table 7). Total bacteria, Azotobacter and Azospirillum counts were in the maximum being ( $160 \times 10^{7} \mathrm{cfu}, 6 \times 10^{6} \mathrm{cfu}$ and $\left.8 \times 10^{6} \mathrm{cfu}\right)$, but lowest value were $15 \times 10^{7} \mathrm{cfu}, 0.7 \times 10^{6} \mathrm{cfu}$ and $0.95 \times 10^{6} \mathrm{cfu}$, respectively.

Generally, it could be concluded that, soil application of humic acid and inoculated cucumber plants with Azotobacter along with 3/4 recommended Nchemical fertilizer dose were the best treatment for maximizing the growth, yield and nutritional status of cucumber plants and low $\mathrm{NO}_{3}$ content in fruits. So, it concluded as the best treatment on basis of yield and $\mathrm{NO}_{3}$ safety for human nutrition. 
Table (7): Effect of humic acid and nitrogen level on total bacteria count and biofertilizers in rhizosphere soil of cucumber plants during 2007 and 2008 seasons

\begin{tabular}{|c|c|c|c|c|c|c|c|}
\hline \multirow{2}{*}{\multicolumn{2}{|c|}{ Treatments }} & \multicolumn{2}{|c|}{$\begin{array}{c}\text { Total bacteria count } \\
\times 10^{7}\end{array}$} & \multicolumn{2}{|c|}{$\begin{array}{c}\text { Azotobacter count } \\
\times 10^{6}\end{array}$} & \multicolumn{2}{|c|}{$\begin{array}{c}\text { Azospirillum count } x \\
10^{6}\end{array}$} \\
\hline & & 2007 & 2008 & 2007 & 2008 & 2007 & 2008 \\
\hline \multirow{7}{*}{ 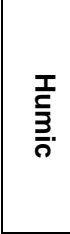 } & $120 \mathrm{~kg} \mathrm{~N} /$ fed.(R) & 94 & 92 & 1.0 & 0.9 & 1.1 & 1.2 \\
\hline & Azt. $+3 / 4$ R & 75 & 74 & 2.8 & 2.5 & 1.8 & 1.7 \\
\hline & Azs. + 3/4 R & 70 & 66 & 2.3 & 2.5 & 2.6 & 2.7 \\
\hline & Azt. + $1 / 2 \mathrm{R}$ & 104 & 102 & 3.3 & 3.1 & 2.3 & 2.2 \\
\hline & Azs. + 1/2 R & 123 & 115 & 3.2 & 3.0 & 4.0 & 4.0 \\
\hline & Azt. + 1/4 R & 109 & 107 & 5.7 & 5.5 & 6.3 & 6.4 \\
\hline & Azs. + 1/4 R & 89 & 84 & 5.6 & 5.12 & 8.0 & 7.8 \\
\hline \multirow{7}{*}{ 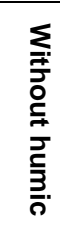 } & $120 \mathrm{~kg} \mathrm{~N} /$ fed.(R) & 78 & 80 & 0.8 & 0.7 & 0.95 & 0.96 \\
\hline & Azt. $+3 / 4 R$ & 160 & 130 & 4.1 & 4.2 & 3.5 & 3.3 \\
\hline & Azs. + 3/4 R & 32 & 34 & 3.3 & 3.1 & 4.5 & 4.4 \\
\hline & Azt. + 1/2 R & 92 & 87 & 5.4 & 5.3 & 5.0 & 4.8 \\
\hline & Azs. + $1 / 2 R$ & 20 & 21 & 5.6 & 5.8 & 6.0 & 6.1 \\
\hline & Azt. + 1/4 R & 95 & 94 & 6.0 & 5.5 & 5.4 & 5.5 \\
\hline & Azs. + 1/4 R & 15 & 16 & 5.8 & 5.2 & 7.0 & 7.1 \\
\hline
\end{tabular}

R: Recommended dose (120 kg N/fed.). Azt: Azotobacter Azs: Azospirillum

\section{REFERENCES}

Abdel-Ati, Y.Y.; A.M.M. Hammad and M.Z.H. Ali (1996): Nitrogen fixing and phosphate solublizing bacteria as biofertilizers for potato plants under Minia condition. Proc. $1^{\text {st }}$, Egyptian -Hungrian, Horticultural conf., Kafr El-Sheik; Egypt 15-17 Sept.

Abd-El-Malek, Y. and Y. Z. Ishac (1968). Evaluation of methods used in counting Azotobacter. J. Appli. Bacteriol., 31: 267-275.

Adani, F.; P.Genevini; P.Zaccheo and Zocchi, (1998): The effect of commercial humic acid on tomato plant growth and mineral nutrition. J. plant nutr. 21: 561-575.

Alexander, M. (1977): Introduction to soil microbiology. $2^{\text {nd }}$ Ed., John Wiley \& Sans., Inc New York.

Anga, M.A. (2001): Studies on the effect of mineral and biofertilization on yield and quality of spinach. M.Sc. Thesis Fac. of Agric., Alex. Univ. Vegetable crops Dept.

Atiyeh, R.M.; S. Lee, C.A. Edwards, N.Q. Arancon, J.D. Metzger (2002): The influence of humic acids derived from earth worm - processed organic wastes on plant growth. Bioresource Technology 84: 7-14.

Awad, El.M.M. and A.M. El-Ghamry (2007): Effect of humic acid effective microorganisms (EM) and magnesium on potato in clayey soil. J. Agric. Sci. Mansoura Univ., 32(9): 7629-7639.

Brown, J.D. and O. Lilleland (1946): Rapid determination of potassium and sodium in plant material and soil extracts by flame photometry. Proc. Amer. Soc. Hort. Sci., 48: 341-346.

Byari, S.H. and Z.M. Mirdad (1996): The response of greenhouse cucumber cultivars to nitrogen sources: 1-Vegatative growth. J.Agric. Sci. Mansoura Univ. 21(5): 1861- 1872.

Chen, Y. and T. Aviad (1990): Effect of humic substances on plant growth. p. 161-186. 
In: Y.Chen and T. Aviad (eds). Humic substances in soil and crop sciences. Amer. Soc. Agron. Soil Sci. Amer., Madison. Wis.

David, P.P.; P.V. Nelson and D.C. Sandres (1994): A humic acid improves growth of tomato seedling in solution culture. J.P. nutrition, 17:173-184.

Difco Manual of Dehydrated Culture Media and Reagents for Microbiological and Clinical Laboratory Procedures (1977). Difco Laboratories Incorporated (9th ED), Detroit , Michigan . USA . 451.

Dobereiner, J. (1988). Isolation and identification of root associated diazotrophs. Plant Soil. 110: 207.

Eickhorst, T. and R. Tippkotter. (2008). Detection of microorganisms in undisturbed soil by combining fluorescence in situ hybridization (FISH) and micropedological methods. Soil Biology \& Biochemistry. 40: 12841293.

Fayez, M.; F.M. Emam and Makboul (1985): The possible use of nitrogen fixing Azospirillum as biofertilizer to wheet plants. Egypt. J. Microbial., 20(2), 199-2006.

Gharib, M.G. (2001): Response of two cucumber cultivars to biofertilization under plastic house condition. M.Sc. Thesis, Fac. of Agric. Cairo Univ. $183 \mathrm{pp}$.

Gilot, C. (1997) Effect of a tropical geophageous earthworm. M. anomala (Megascolecidae) on soil characteristics and production of yam crop in Ivory Coast. Soil Biology and Biochemistry 29: 353-359.

Gomaa, A.M.H. (1995): Response of certain vegetable crops to biofertilization. Ph.D. Thesis, Fac. Agric., Cairo Unvi. Egypt.

Gupta, S.; D.K. Arora and A.K. Srivastava (1995): Growth promotion of tomato plants by rhizobacteria and imposition of energy stress on Rhizoctonia solani. Soil Biology and Biochem., 27: 1051-1058.

Hammad, A.M.M. and Y.Y. Abdel-Ati (1998): Reducing of nitrate and nitrite contents of potato tubers via biofertilization with Azospirillum and VAmycrohizal fungi. J. Agric. Sci. Mansoura Univ., 23(6): 2597-2610.

Hanna, m.m.; S.A. Kabeel and F.M.A. Darwish (2005): Effect of organic and biofertilizers on growth yield and fruit quality of cucumber (Cucumis sativus L.) grown under clear polyethylene low tunnels. J. Agric. Sci., Mansoura Univ., 30(5): 2827-2841.

Kahsnitz, H.G. (1992): Investigations on the influence of earthworms on soil and plant. Botanical Archives (I), 315-331.

Liu, C.R.; J. Cooper and D.C. Bowman (1998): Humic acid application affect photosynthesis, root development and nutrient content of creeping bentgrass. Hort. Sci., 33: 1023-1025.

Mahmoud, E.; N. Abdel-Kader; P.Robin; N. Akkal and Lamyaa AbdelRahman (2007): Effect of different organic and inorganic fertilizers on cucumber yield and some soil properties. World Journal of Agricultural Sciences 5(4): 408-414.

Murphy, J. and J.P.R. Riley (1962): A modified single solution method for determination of phosphorus in natural waters. Anal. Chem. Acta., (27): 31-36.

Oxoid Manual of Culture Media, ingredients and other laboratory services other laboratory services (1965), London.

Pregl, E. (1945). Quantitative organic microanalysis. $4^{\text {th }}$ Ed. Chunndil, London. 
Reynders, L. and K. Vlassak (1982) Use of Azospirillun brasilense as biofertlizer in intensive wheat cropping. Plant and Soil, 66, 217.

Singh, J.P. (1988): A rapid method for determination of nitrate in soil and plant extracts. Plant and Soil. 110: 137-139.

Smidova, M. (1960): The influence of humic acid on the respiration of plant roots, Biol. Plant. 2: 152-164.

Snedecor, G.W. and Cochran, W.G. (1980). Statistical methods $7^{\text {th }}$ Ed. The lowa State Univ. Press Ames, lowa, U.S.A.

Subba Rao, N.S. (1982): Advances in agricultural microbiology. Oxford \& IBH publishing Co. New Delhi, India.

Tien, T.M.; M.H. Gaskins and D.H. Hubble (1979): Plant growth substances produced by $A$. brasilense and their effect on the growth of pearl millet. Appl. Environ. Microbiol. 37, 1016.

Tomati, U. and E. Galli (1995): Earthworms soil fertility and plant productivity. Acta Zoolgica Fennica 196, 11-14.

Zhang, X.; E.H. Ervin and R.E. Schmidt (2003): Physiological effects of liquid applications of a seaweed extracts and humic acid on creeping. J.Amer. Soc. Hort. Sci. 128(4): 492-496.

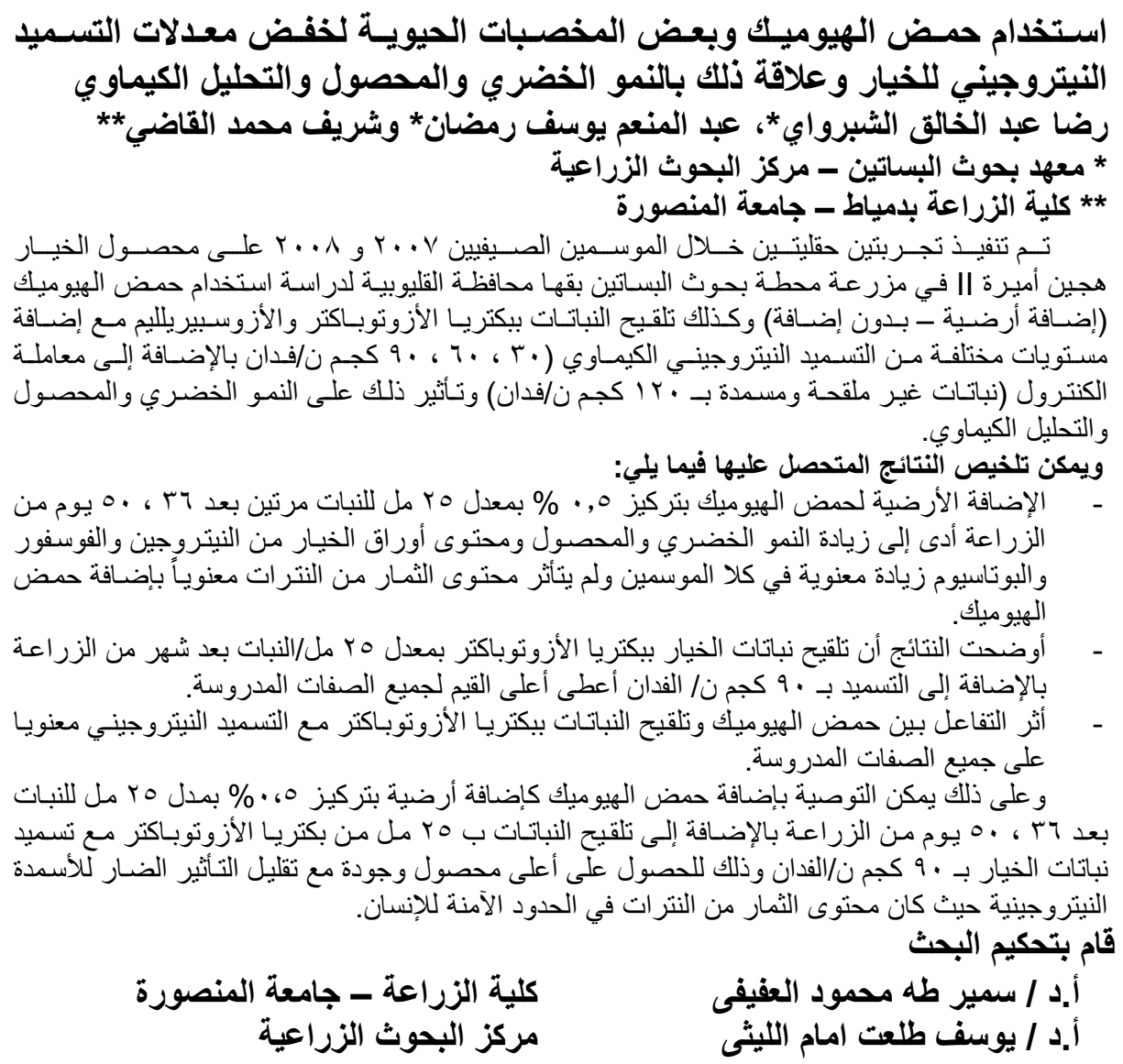

